\title{
Mapping of Domestic Hot Water Circulation Losses in Buildings - Preliminary Results from 134 Measurements
}

\author{
Stephen Burke ${ }^{1,2,}{ }^{*}$, Jonatan von Seth $^{3}$, Tomas Ekström ${ }^{1,2}$, Christoffer Maljanovski ${ }^{1}$, and Magnus Wiktorsson ${ }^{2}$ \\ ${ }^{1} \mathrm{NCC} \mathrm{AB}$ \\ ${ }^{2}$ Lund University \\ ${ }^{3}$ Gunnar Karlsen Sverige AB
}

\begin{abstract}
The hot water circulation system in a building is a system which helps prevent Legionella problems whilst ensuring that tenants have access to hot water quickly. Poorly designed or implemented systems not only increase the risk to people's health and thermal comfort, but even result in an increase in the energy needed for this system to function properly. Results from previous studies showed that the total hot water circulation system loss can be as high as $25 \mathrm{kWh} / \mathrm{m}^{2}$ heated floor area per year. The purpose of this project is to measure the total energy use per year of the hot water circulation system in about 200 multifamily dwellings of different ages to verify that a system loss of $4 \mathrm{kWh} / \mathrm{m}^{2}$, year is a realistic assumption for both newer and older/retrofitted buildings. The preliminary results from the first 134 measurements showed that the assumption of $4 \mathrm{kWh} / \mathrm{m}^{2}$, year is rarely fulfilled. An average energy use of more than three times this is more common, even in newer buildings. Whilst some of the total energy lost is used to heat the buildings, it is not desirable because it is an uncontrolled energy flow.
\end{abstract}

\section{Background}

The domestic hot water circulation system (DHWC) in a building is a system that continually circulates the domestic hot water (DHW) within a building, see Fig. 1. DHW is heated in the hot water heater and sent out to the apartments. Hot water that is not used is sent back in a loop to the hot water heater to be re-heated back to the set DHW temperature and is sent back out to the apartments. This system operates continually.

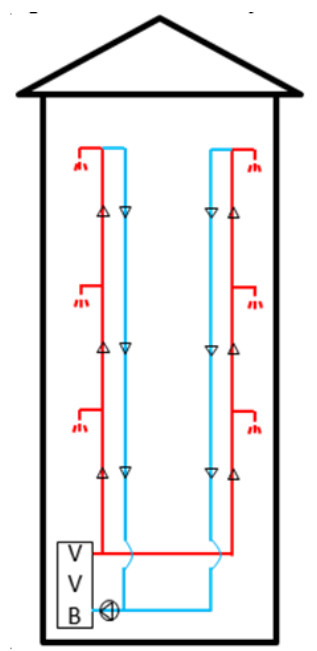

Fig. 1: An example of a DHWC system in a multifamily building.
This system is used in Sweden as a means of ensuring people have access to hot water quickly while at the same time preventing problems with Legionella. The Swedish National Board of Housing, Building and Planning (Boverket) has several requirements which must be fulfilled as well as recommendations that should be fulfilled when designing and installing hot water circulation systems in buildings. [1] (BBR)

One of the recommendations is that the tenant should get hot water (between $50{ }^{\circ} \mathrm{C}$ and $60^{\circ} \mathrm{C}$ ) within 10 seconds, assuming a DHW flow of $0,2 \mathrm{l} / \mathrm{s}$. Some interpret this recommendation such that the water should be hot without using more than 2 litres of water. One of the regulations is that the return line of the circulation system shall not have a lower temperature than $50{ }^{\circ} \mathrm{C}$. In practice, if the return line temperature is too low with the designed flow, the flow of the DHWC system is adjusted up so that the return temperature is a little over $50^{\circ} \mathrm{C}$.

This should be done without using too much energy. Low energy buildings, Passive Houses and nearly Zero Energy buildings (nZEB) use less energy than before and the DHW and DHWC losses are becoming a more significant part of a building's energy loss. Renovating a building with a focus on energy use presents several different challenges. While DHW is often reduced by installing low-flow facets, the DHWC system is often overlooked and as a result can ruin the total energy performance of a building. This was the case with the Swedish object within the E2Rebuild project (building from 1963 renovated between 2011 and 2013) where a

*Corresponding author: Stephen.burke@ncc.se 
DWHC system energy use was assumed to be the Swedish standard of about $4 \mathrm{kWh} / \mathrm{m}^{2}$ year (ca $6178 \mathrm{~m}^{2}$ heated floor area, 91 apartments built in 1963). [2] The first measurements indicated that the combined DWH and DHWC energy use was about $20 \mathrm{kWh} / \mathrm{m}^{2}$ year (based on measured DHW use + assumed DHWC). A deeper analysis done after the E2Rebuild report (unpublished from 2017) with more detailed measurements showed that the DWH actually had an energy use of about 15 $\mathrm{kWh} / \mathrm{m}^{2}$ year and the DWHC was about $28 \mathrm{kWh} / \mathrm{m}^{2}$ year, almost double the DWH energy per year. The heat loss in this case was due to a combination of poorly insulated pipes and the total length of the system. For example, the pipes running through the underground parking garage had no insulation. There was also a large length of pipe which ran under the basement slab servicing other parts of the building. It was unknown if there was insulation on these sections or not.

\subsection{Previous studies of DHWC losses}

Several studies have been done to determine the actual losses from the DHWC system in existing buildings in Sweden. The Swedish building code states that DHWC losses must be included in a building's primary energy use calculation. Therefore, it is valuable to have information on the energy use of such systems in practice so that it is not underestimated during the design stage.

In 2017, the Swedish Building Service (Svenskbyggtjänst) wrote a summary of different technical solutions used for hot water circulation systems and how to make them more energy efficient [3]. The summary presented results from several studies [4-6], and various technologies to reduce DHWC losses in future projects.

In Alros, [4], the hot water circulation system losses in two apartment buildings were measured to be 11 and $37 \mathrm{kWh} / \mathrm{m}^{2}$ heated floor area and year respectively. In Bergqvist [5], the hot water circulation systems losses were measured in 12 apartment buildings. The results of this study showed that the losses varied between 2.3 and $28 \mathrm{kWh} / \mathrm{m}^{2}$ per year, with an average value of $9.1 \mathrm{kWh} / \mathrm{m}^{2}$ per year. Bergqvist also wrote in a later report that in Sweden, a value of $4 \mathrm{kWh} / \mathrm{m}^{2}$ per year is often the assumed DHWC system loss when doing energy calculations [6].

In a 2014 study by Lindencrona and Lindsköld, [7], the total heat loss from the DWHC system for 540 buildings (mainly residential) were measured. The measurements were done during hot summer nights to reduce the risk of other factors influencing the results. The results showed an average loss of $17.4 \mathrm{kWh} / \mathrm{m}^{2}$ per year. This figure should be seen as a potentially worst-case scenario as it is unknown how other heat sources, such as transmission losses in the utility room, DHW use, active heating systems (circulation pumps) and other types of heating systems impact the measurements. These potential heat sources are not uncommon during the summer months, even though there is no heating need [7].

An SBUF report by Kempe from 2013, [8], reports that hot water circulation losses in a multi-family building are usually between $5-8 \mathrm{kWh} / \mathrm{m}^{2}$ year but can be as high as $20-25 \mathrm{kWh} / \mathrm{m}^{2}$ year in some cases. The report also recommends several solutions for designers/engineers to minimize these losses, for example by shortening the length of the system in apartments by placing washrooms and kitchens close to the service point (less than 12 meters). [8]

\subsection{Purpose of this paper}

The purpose of this paper is to present the first short-term DHWC energy losses measured in the project and compare them with values from the literature study.

The purpose of the project is to:

- Document and collect building information and measured values for different multi-family buildings built at different time periods.

- Document and collect measured values for newer multi-family buildings creating a feedback loop back to designers

- Test various simplified methods of calculating the DHWC system energy losses using information such as pipe length, insulation thickness, flowrates, etc.

\subsection{Limitations}

This paper has several limitations. The objects are only multi-family dwellings. The objects have a variation of building years which are dependent on the distribution of the number of multi-family buildings built each year in Sweden. Fig. 2 shows the number of planned measurements for various building years based on the building stock in Sweden. This paper presents preliminary results and only what has been measured to date. The results are not yet analysed and several objects with unusual results will be analysed in more detail in the spring of 2021.

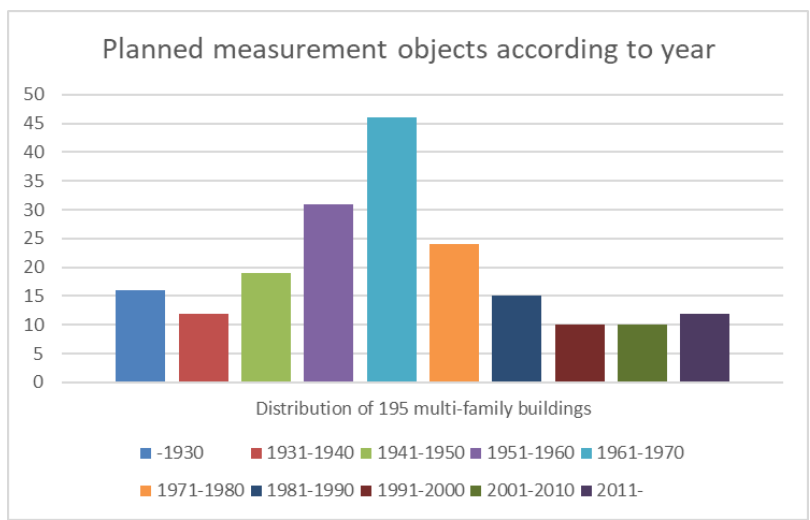

Fig. 2: The planned objects in this study are based on the distribution of building multi-family buildings in Sweden.

This paper presents measured values and the data has not been completely verified. Some errors can still be present in the presented data; however, the data has been checked after the measurement periods for values that could indicate problems with the measurement equipment. When uncertain if there was a problem with 
the measurement in a building (such as extremely high values), a second measurement period with different equipment has been used to verify the first measured values.

Errors from the measuring equipment have not been analysed but will be taken into account during the final analyses.

Another limitation in this paper is that most of the preliminary results show the total energy use per year for the DHWC system. In order to convert these into energy loss outside of the heating season, the power signature of the building must be known in order to determine the balance temperature of the building.

The presented measurements can contain data collected during unknown problems with the DHWC system (such as a temporary low-flow or incorrect temperatures due to bad sensors or pumps). Efforts to reduce the risk of these types of errors have been taken before the measurement periods, such having as open communication with all the object owners regarding operational stability and errors/faults.

\section{Method}

\subsection{Measured buildings and methods of measurement}

The project will collect DHWC heat losses and associated information for the building and it's DHW system using several methods. A total of 195 short-term measurements will be done using calibrated, portable measuring equipment. More on the measuring equipment can be found in 2.1 Measuring Equipment. In addition to this, at least 50 measurements will be collected in newer buildings with the object's integrated measurement equipment (built in to the hot water circulation system). Finally, five long-term measurements are being done using portable, calibrated equipment.

The collected dataset on each building includes, when possible, parameters such as estimated pipe length, number of apartments, number of stairwells, floors, heated floor area, DHWC flow, temperatures (cold water, DHW, DHWC), insulation thickness (DHW and DHWC), uninsulated pipe length, pipe diameter, number of shafts, IR images, type of insulation, estimated DWH use, and more. This data is collected from drawings (when available), historical measurements from the building's systems, measurements done on site within the context of this project and information obtained from the building owner.

The short-term measurements with portable measuring equipment are done over a five-day period. To minimise effects of mounting and dismounting equipment, only the three middle days over the five-day period are used in the data analyses. This means that the measurement period during the days when the equipment is put out and retrieved is excluded. This results in three 24-hour periods measuring from 00:00 to 23:59. Longterm measurements are one year using the same equipment types as the short-term measurements.
The measuring principle is to measure the water temperature in the return before the water heater (\#1 in Fig. 3), the water temperature leaving the water heater $(\# 2)$, and the water flow of the DHWC system (\#3).

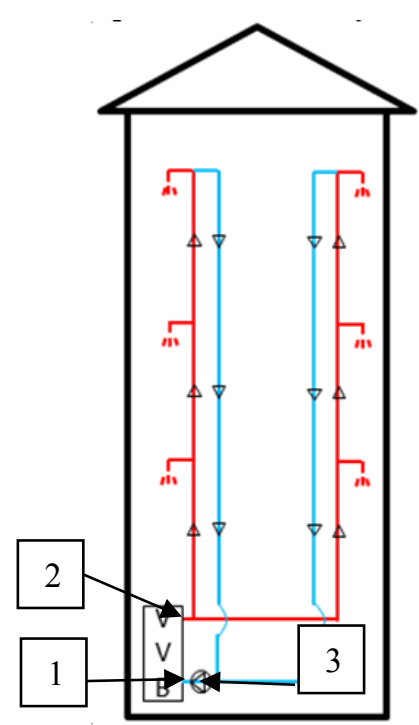

Fig. 3: Measurement points in the DHWC system.

With this information you can calculate the total energy use of the system according to:

$$
E=c * q * \rho *\left(T_{D H W}-T_{H W C}\right) * t
$$

where

$E=$ energy $[\mathrm{kWh} /$ year $]$

$c=$ Specific heat capacity of water, $4,186 \mathrm{KJ} / \mathrm{Kg}^{\circ} \mathrm{C}$

$q=$ Water flow $[1 / \mathrm{s}]$

$\rho=$ Density of water, 0,985 Kg/1@ $@ 56{ }^{\circ} \mathrm{C}$

$\mathrm{T}_{\mathrm{DHW}}=$ Temperature of Domestic Hot Water $\left[{ }^{\circ} \mathrm{C}\right]$

$\mathrm{T}_{\mathrm{HWC}}=$ The return temperature of the hot water circulation before heating $\left[{ }^{\circ} \mathrm{C}\right]$

$t=8760$ hours per year

Observe that the short-term measurements are extrapolated to show the total energy use per year for the DHWC system. If the energy use outside of the heating season is required (for example when it is assumed that the DHWC system energy losses heat the building), then $t=$ hours building is not heated. In this case the time depends on the balance temperature of the building and the local climate. See Eriksson et. al. [9] for more information about how this can be done in practice.

\subsection{Measuring equipment}

Flow measurements are done with an ultrasonic measurement device, Fluxus F601. The instrument provides instantaneous measurements. The accuracy depends on the calibration method used, standard calibration gives an accuracy of $\pm 1,6 \%$ of the reading, extended calibration gives an accuracy of $\pm 1,2 \%$ of the reading and field calibration gives an accuracy of $\pm 0,5 \%$ of the reading. [10]

Temperature measurements are done with two Tinytag Ultra 2 with external sensors. The sensors are 
attached directly to the DHW pipe after the heat exchanger, and the return line before the cold-water pipe. The accuracy of the Tinytag Ultra 2 is $\pm 0,45^{\circ} \mathrm{C}$. [11]

\section{Preliminary Results and discussion}

\subsection{Measured energy use}

It is important to observe that the project is still gathering data from different projects and none of the data is analysed. This paper presents the preliminary results from the first 134 buildings in Fig. 4 and Fig. 5.

The values in Fig. 4 are shown as the total energy use per year for the DHWC system for objects 1 to 134 and range from $0,5 \mathrm{kWh} / \mathrm{m}^{2}$ year to $76 \mathrm{kWh} / \mathrm{m}^{2}$ year.

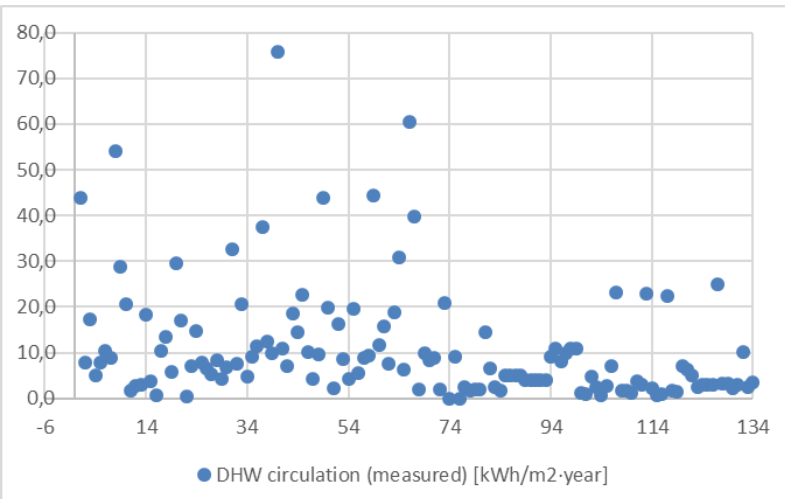

Fig. 4 : Preliminary measured values of DHWC in 134 multifamily houses in Sweden shown as $\mathrm{kWh} / \mathrm{m}^{2}$ (heated floor area) year.

Fig. 5 shows both the measured and calculated energy use (when available) for objects 100 to 134 . These objects are newer than 2015. In Sweden, this is not always calculated specifically for the project and in these cases, a value of $4 \mathrm{kWh} / \mathrm{m}^{2}$ year was assumed.

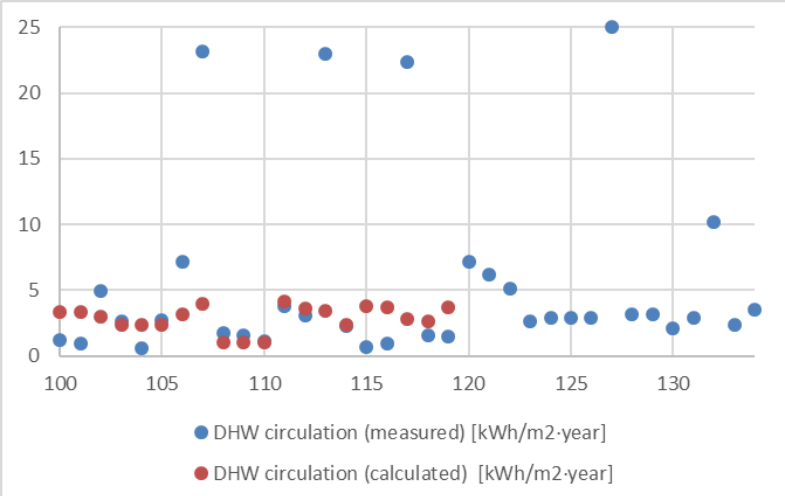

Fig. 5: Preliminary measured energy use of the DHWC system outside of the heating season in 34 multifamily houses newer than 2015 in Sweden shown as $\mathrm{kWh} / \mathrm{m}^{2}$ (heated floor area) year.

To be able to see if there was any trend between the age of the building and the energy use of the DHWC system, the measured energy use data was plotted against building year. Fig. 6 shows that all buildings have a large variation in the DHWC system losses no matter what year it was built, with the highest value recorded from 2001 . The largest value $\left(76 \mathrm{kWh} / \mathrm{m}^{2}\right.$ year) had to be verified since it was thought that an error occurred during the measurement time. A new measurement with newly calibrated equipment showed that this result was correct.

Fig. 7 shows that this spread can still be large even in new buildings. However, looking at the average DHWC system energy uses, older buildings have an average energy use of $14 \mathrm{kWh} / \mathrm{m}^{2}$ year and the newer buildings have an average energy use of $6 \mathrm{kWh} / \mathrm{m}^{2}$ year.

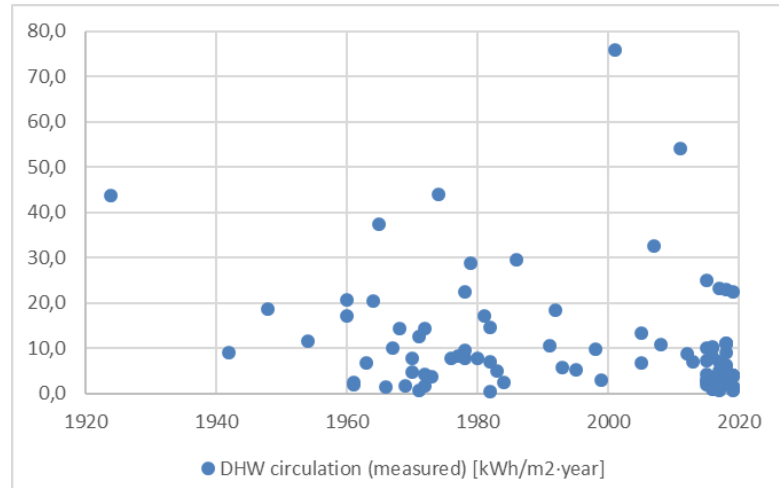

Fig. 6: Preliminary measured total energy use of DHWC shown as $\mathrm{kWh} / \mathrm{m}^{2}$ (heated floor area) year vs building year (1924-2015).

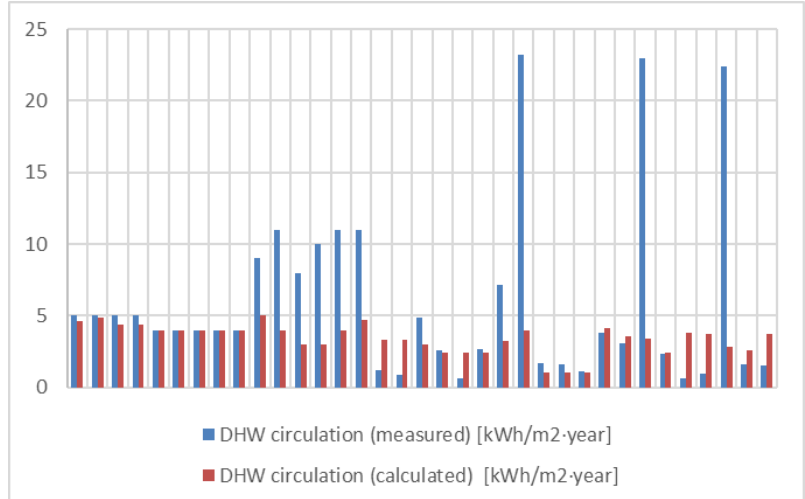

Fig. 7: Preliminary measured and calculated energy use of DHWC energy use shown as $\mathrm{kWh} / \mathrm{m}^{2}$ (heated floor area) year for all buildings with available calculated energy use from the design phase

\subsection{Comparison between measured and calculated energy use}

In some of the newer buildings built between 2016 and 2019, the calculated energy use for the DHWC system was provided. The difference between the measured versus calculated energy use is shown in Fig. 8.

Some of the objects, for example 1-9, 19, 21, 24-28 show good agreement whilst others, such as objects 23 , 29 and 33 have very high measured values. 


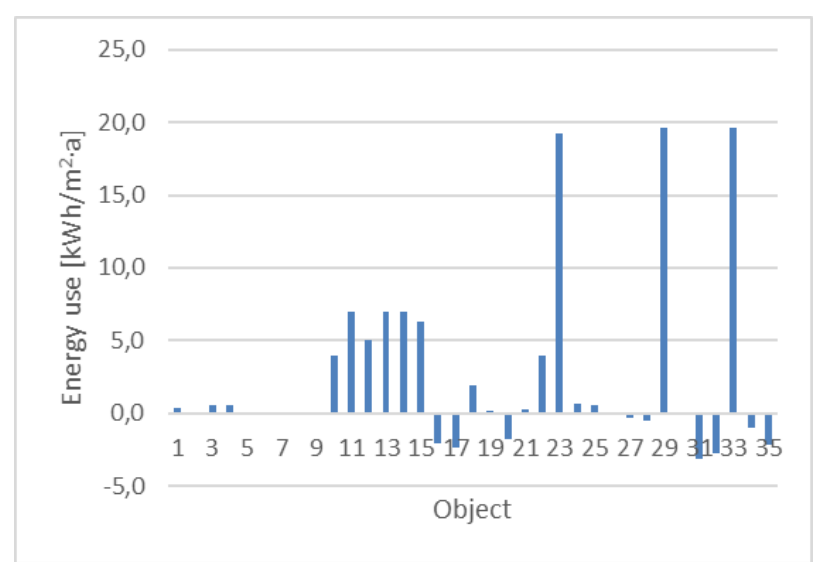

Fig. 8: Differences between measured versus calculated energy use values of DHWC in 35 of the newer multifamily houses (2016-2019).

It is not yet known why there is such a large variation in these DHWC systems and the explanation for these differences may vary in each case. For example, the explanation for the high energy use in the system with the highest measured value of $76 \mathrm{kWh} / \mathrm{m}^{2}$ year was partly documented. It is a quattro pipe system, see Fig. 9, which has a long length of pipe underground from a central distribution point to several buildings.

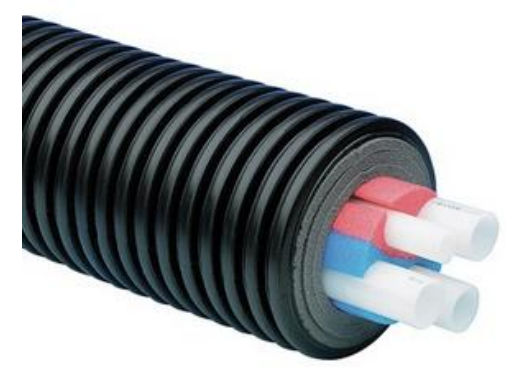

Fig. 9: Quattro pipe found in the multifamily buildings in one case.

In this case we know that the quattro pipe contains the DHW and DHWC along with a low temperature heating loop (supply and return from hot water radiators). After talking to a representative from the building owners, it seems that there is a significant heat transfer from the DHWC system to the low-temperature heating system. This was made apparent during the summer months when it was observed by building owners that the radiator system can still have water over $30^{\circ} \mathrm{C}$. The length of the system also means that there is a large heat loss to the ground so much of the heat lost is not used in the buildings.

The other extreme is when the energy use is very low. In one such case where the energy use was below 0,5 $\mathrm{kWh} / \mathrm{m}^{2}$ year, it was noted on site using thermography that the DHWC system had a "short circuit" in the system. This meant that there was a section of pipe that sent the DHW back to the water heater shortly after it left.

From this case, it is important to note that low energy values (less than $2 \mathrm{kWh} / \mathrm{m}^{2}$ year) do not mean that the DHWC system is more energy efficient. This system does not likely fulfil the Swedish building code because the hot water temperature in the system does not stay above $50{ }^{\circ} \mathrm{C}$. This has brought up the question of if the extremely low energy losses are because of an energy efficient design, or if they indicate a DHWC system which is faulty.

Another observation in several cases is that the DHWC pipes sometimes go through the concrete floor with not insulation. This results in energy losses due to thermal bridges.

The analyses phase of the project has not yet begun, and further analyses will be done on the dataset once it is complete.

\section{Conclusions and future work}

The preliminary results showed that the DHWC systems used in Swedish multi-family buildings have a large variation in energy losses between what is assumed/calculated and measured. The preliminary results even show that newer DHWC systems used in Swedish multi-family buildings are a little more energy efficient than those from previous years but the DHWC system still needs to be taken into account in both new buildings and when implementing energy efficient measures on existing buildings.

Since this project is still ongoing, measurements will be continued over 2020 and 2021. Several cases will be chosen for further investigation regarding their very high or extremely low energy use in order to determine if the system performed as designed and why their energy use deviates. Some possible explanations to both high and low energy use which will be looked at include losses due to thermal bridges (when the DHWC system goes through a concrete floor with less/no insulation), differences in DHWC systems (like the Quattro pipe) and the prevalence of short circuits.

The authors would like to thank SBUF (www.sbuf.se) and E2B2 (www.e2b2.se) for funding this study. We would also like to thank our reference group for all their ideas, feedback, and enthusiasm! Finally, we would like to thank all the building owners who have agreed to let us measure for a week in their multi-family buildings!

\section{References}

1. Boverkets byggreglar, Consolidated version of Boverkets building regulations (in Swedish), Available at: https://www.boverket.se/sv/lag-ratt/forfattningssamling/gallande/bbr---bfs-20116/ Last accessed : 2020-01-20 (2019)

2. S. Burke, Industrial Energy Efficient Retrofitting of Resident Buildings in Cold Climates - D2.5 Demonstrator Halmstad. Malmö. Available at: https://smartcities-

infosystem.eu/sites/www.smartcitiesinfosystem.eu/files/e2rebuild_demonstrator_halmsta d.pdf. (2014)

3. M. Östlund, and D. Öhman, DHWC and energy efficiency measures - a summary (VVC-ledningar och energieffektivisering - Sammanfattning.) (in Swedish), Available at: 
https://omvarldsbevakning.byggtjanst.se/contentasse ts/ed64f0be09954312a9984d843439338c/vvc-

ledningar-och-energieffektivisering---

sammanfattning-till-kund-ny.pdf. (2017)

4. M. Alros, Energy mapping of DHWC system in multifamily dwellings (Energikartläggning av VVCsystemet i flerbostadshus.) (in Swedish), Stockholm. Available at: http://kth.divaportal.org/smash/record.jsf?pid=diva2\%3A808048. (2015)

5. B. Bergqvist, $D H W C$ losses in multi-family buildings - mapping of 12 properties (VVC-förluster $i$ flerbostadshus - Kartläggning $i 12$ fastigheter.) (in Swedish), Stockholm. Available at: https://www.bebostad.se/library/1893/slutrapportkartlaeggning-av-vvc-foerluster.pdf. (2015)

6. B. Bergqvist, DHWC-losses in offices and industries - measurements in 11 buildings (VVC-förluster $i$ kontor och lokaler - mätningar i 11 byggnader.) (in Swedish), Stockholm. Available at: https://www.energi-

miljo.se/sites/default/files/vvc lokaler_slutrapport_2 0161129.pdf. (2016)

7. E. Lindencrona and S. Lindsköld, Pre-study of DHWC-losses in multi-family buildings (Förstudie av $V V C$-förluster $i$ flerbostadshus.) (in Swedish), Stockhom. Available at: https://www.bebostad.se/library/1880/foerstudierapp ort-vvc-foerluster-i-flerbostadshus.pdf. (2014)

8. P. Kempe, Building services in energy efficient buildings - a Pre-study (Installationssystem $i$ energieffektiva byggnader - Förstudie.) (in Swedish), Stockholm. Available

https://www.feby.se/files/201901/installationssystem-sbuf-12541.pdf. (2013)

9. M. Eriksson, J. Akander, and B. Moshfegh, Energy and Buildings, 210, Article 109756 (2020)

10. Fluxus F601 product information, https://www.omniprocess.se/produkter/flode/ultralju d/ last accessed: 2020-01-19

11. Tinytag Ultra 2 - external temperature product information,

https://intab.se/catalog/products/tinytag-ultra-2extern-temperatur-fast-monterad last accessed: 202001-19 